\title{
Hexavalent Chromium Reduction by Anoxybacillus rupiensis isolated From Hot Water Spring of Dhapoli, Maharashtra, India
}

\section{Gursahani YH ${ }^{1 *}$ and Gupta SG ${ }^{2}$}

${ }^{1}$ Department of Biotechnology, Government Institute of Science, Nipatniranjan Nagar, Caves Road, Aurangabad (M.S), India

${ }^{2}$ Government Institute of Forensic Science, Nipatniranjan Nagar, Caves Road, Aurangabad (M.S), India

\begin{abstract}
A novel thermophile, aerobic, Gram positive, spore forming bacterium isolated from hot water springs of Dhapoli, Maharashtra; India. The isolate was able to ferment a wide spectrum of sugars, polyols, and polysaccharides like xylan, glycogen and starch. Optimal growth was observed at $60^{\circ} \mathrm{C}$, and $\mathrm{pH}$ at 6.5 . Phylogenetic analysis of the whole 16S rRNA gene sequence clustered the strain T4 with the representatives of the genus Anoxybacillus and with Geobacillus tepidamans. The G+C content of the genomic DNA was $41.7 \%$. Fatty acid profile (major fatty acids iso-C15:0 and iso-C17:0) confirmed the affiliation of the strain to the genus Anoxybacillus. Anoxybacillus rupiensis showed $75 \%$ of $\mathrm{Cr}(\mathrm{VI})$ reduction after 24 hours of incubation. Our results have confirmed that Anoxybacillus rupiensis is one of the most prominent thermophiles that could be exploited for the treatment of chromium bearing effluents.
\end{abstract}

Keywords: Thermophiles; Hot water springs; Anoxybacillus rupiensis; 16sRNA gene analysis; $\mathrm{Cr}(\mathrm{VI})$ reduction.

\section{Introduction}

The first representative of the genus Anoxybacillus, A. pushchinoensis was described by Pikuta [1] as strictly anaerobic and an emended description of the species was published later on Pikuta [2] according to which this species should be considered as aerobic anaerobe and the genus Anoxybacillus should be emended to aerobic anaerobes and facultative anaerobes. Although the name of the genus Anoxybacillus means "without oxygen Bacillus", according to Pikuta [1], most of the species described grow well aerobically and even for some species anaerobic growth was registered only under certain conditions [3]. The Bacillacea family members are good source of bacteria for bioprocessing and biotransformation involving whole cells or enzymes. In contrast to Bacillus and Geobacillus, Anoxybacillus is relatively new genus that was proposed in the year 2000. Because these bacteria are alkali tolerant thermophiles, they are suitable for many industrial applications.

More than a decade after the first report of Anoxybacillus, knowledge accumulated from fundamental and applied studies suggest that the genus can serve as a good alternative in many applications related to environmental waste water treatment, dye degradation [4] enzyme technology, and possibly bioenergy production [5]. There are many reports regarding the reduction of $\mathrm{Cr}$ (VI) which is soluble and toxic form into $\mathrm{Cr}$ (III) insoluble non- toxic form by mesophilic aerobic bacteria. A great deal of work has been carried out on aerobic reduction of Cr (VI) by Pseudomonas sp. Literature survey has confirmed only few reports on reduction of $\mathrm{Cr}$ (VI) by aerobic thermophilic bacteria. This generated interest to check the potential of the isolated aerobic thermophilic bacteria for $\mathrm{Cr}(\mathrm{VI})$ reduction. Generally, aerobic bacteria when grown under anerobic conditions, $\mathrm{Cr}$ (VI) serves as a terminal electron acceptor. During metabolism, electrons released as a result of oxidation of energy sources, NAD and FAD are reduced to $\mathrm{NADH}_{2}$ and $\mathrm{FADH}_{2}$. This in turn donates the electrons to the different redox carriers of electron transport chain of aerobic bacteria. Finally, the electrons are accepted by $\mathrm{Cr}$ (VI) and reduced into $\mathrm{Cr}$ (III).

Dhapoli, a small town in Ratnagiri district of Maharashtra State of India is rich in geothermal water sources, recording the highest temperature of $71^{\circ} \mathrm{C}$ and has $\mathrm{pH}$ 6.5. Although, thermophilic producers of biotechnologically valuable enzymes were isolated from Unhavre at Dhapoli hot water springs but their ability was not assessed for biodegradation purposes. In this study the phylogenetic, physiological and biochemical properties of a novel isolate Anoxybacillus rupiensis and the assessment of its ability to reduce $\mathrm{Cr}$ (VI) on lab scale, are described.

\section{Material and Methods}

\section{Sample collection and enrichment}

The hot water was collected from the hot water spring source into sterile steel thermos. Soil Samples were also collected from the same source at the depth of $1 \mathrm{~m}$ and taken in $100 \mathrm{ml}$ sterile bottles. Both dilution plate method and enrichment method were used for isolation of aerobic thermophilic bacteria [6].

From the enrichment method, $10 \mathrm{~g}$ or $10 \mathrm{ml}$ of samples were transferred into $100 \mathrm{ml}$ of Thermus broth media. Incubation was performed in stationary shaker at $60^{\circ} \mathrm{C}$ until turbidity was observed. Then $500 \mu$ of the broth was plated on the Thermus media plates; where in Gelarite was used as a solidifying agent. For the dilution plate method, $10 \mathrm{~g}$ soil or $10 \mathrm{ml}$ of water samples were transferred in $90 \mathrm{ml}$ of $0.85 \%$ saline water. The mud samples only were pasteurized for 10 minutes at $80^{\circ} \mathrm{C}$ in a waterbath in order to kill most of the vegetative cells and thus to eliminate non-spore forming bacteria. Following the heat treatment, $1 \mathrm{ml}$ aliquots from each sample was transferred in $9 \mathrm{ml}$ of $0.85 \%$ saline water and 6 fold dilutions were prepared. One $\mathrm{ml}$ of the dilutions was plated on Thermus solid media and incubated for $24 \mathrm{~h}$ at $60^{\circ} \mathrm{C}$. The plates were covered with cooking bags to prevent drying of

*Corresponding author: Gursahani YH, Department of Biotechnology Government Institute of Science, Nipatniranjan Nagar, Caves Road, Aurangabad (M.S), India, Tel: +919890497439; E- mail: yash18@gmail.com

Received April 20, 2015; Accepted June 30, 2015; Published July 10, 2015

Citation: Gursahani YH, Gupta SG (2015) Hexavalent Chromium Reduction by Anoxybacillus rupiensis isolated From Hot Water Spring of Dhapoli, Maharashtra, India. J Pet Environ Biotechnol 6: 232. doi:10.4172/21577463.1000232

Copyright: ( 2015 Gursahani $\mathrm{YH}$, et al. This is an open-access article distributed under the terms of the Creative Commons Attribution License, which permits unrestricted use, distribution, and reproduction in any medium, provided the original author and source are credited. 
Gelarite at this temperature. Single colonies were picked and they were purified using streak plate method [6].

\section{Culture medium and growth conditions}

The samples were enriched in Thermus medium, containing $(\mathrm{g} / \mathrm{l})$ : peptone (Difco)-3, $\mathrm{NaCl}$ (Difco)-1, yeast extract (Difco)-2, Beef extract (Difco)-0.2, $\mathrm{pH}$ of the medium was adjusted before autoclaving to 7.0 using $1 \mathrm{M} \mathrm{NaOH}$. Cultures were incubated overnight at $60^{\circ} \mathrm{C}$. The same medium supplied with $3 \%$ Gelarite (a substitute for agar) was used for obtain pure cultures.

\section{Phenotypic characterization}

Isolates were grown on sporulation media for 2 days. The cells were suspended in 3-5 $\mu \mathrm{l}$ of sterile distilled water on a glass slide and covered with another slide. Endospores were observed under the phase contrast microscope.

The effect of $\mathrm{pH}$ on growth was determined in the area 5.0-9.0 with $0.5 \mathrm{pH}$ steps using acetate (for $\mathrm{pH}$ 5-5.5), phosphate (for $\mathrm{pH} 5.5-8.0$ ) or glycine- $\mathrm{NaOH}$ (for $\mathrm{pH} 8.0-9.0$ ) buffers at concentration $0.05 \mathrm{M} . \mathrm{pH}$ values were adjusted at room temperature. The influence of temperature on growth was determined at $\mathrm{pH} 6.5$ at different temperature with $5^{\circ} \mathrm{C}$ steps. Methods described by Smibert and Krieg were used for physiological characterization of the strains. Catalase activity was assayed by mixing a pellet of freshly centrifuged $6 \mathrm{~h}$ culture with a drop of $3 \%$ hydrogen peroxide. Their ability to utilize different sugars was examined in a minimal salt medium (MSM) consisting of $(\mathrm{g} / \mathrm{l})$ : $\left(\mathrm{NH}_{4}\right)_{2} \mathrm{HPO}_{4}, 1.0 ; \mathrm{KCl}, 0.2 ; \mathrm{MgSO}_{4}, 0.1$; thiamine, 1.10-6; bromthymol blue, 1.10-4. Sugars were added at final concentration of $0.1 \%(\mathrm{w} / \mathrm{v})$.

Sugars tested were: L-arabinose, ribose, xylose, fructose, glucose, galactose, manose, L-rhamnose, sucrose, lactose, maltose and raffinose. Polyols examined were: adonitol, dulcitol, inositol, mannitol and sorbitol. The following polysaccharides were used: glycogen, inulin, pectin, salicin and xylan. Sugars were sterilized separately and thiamin was sterilized by filtration. Selected compounds were tested as nitrogen sources: peptone, yeast extract, casein, gelatin, urea and $\left(\mathrm{NH}_{4}\right)_{2} \mathrm{HPO}_{4}$. They were added in the concentration of $0.1 \%$ in ammonium free mineral medium (MSM without $\left(\mathrm{NH}_{4}\right)_{2} \mathrm{HPO}_{4}$ and bromothymol blue) with $2 \mathrm{~g} / \mathrm{l}$ glucose as a carbon source.

\section{Genomic studies}

Sequence data of $16 \mathrm{~S}$ rRNA was generated for each phenotypically unique isolate which grew to the highest dilution in each enrichment type. This was used for identification. DNA was isolated from the culture provided. Its quality was evaluated on $1.2 \%$ Agarose gel, until a single band of high-molecular weight DNA was observed. Fragment of $16 \mathrm{~S}$ rDNA gene was amplified by PCR with the use of universal primers from the above isolated DNA. A single discrete PCR amplicon band of 1500 bp was observed when resolved on Agarose gel. The PCR amplicon was purified to remove contaminants. Forward and reverse DNA sequencing reaction of PCR amplicon was carried out with $8 \mathrm{~F}$ and 1492R primers using BDT v3.1 Cycle sequencing kit on ABI 3730xl genetic analyzer. Consensus sequence of $1405 \mathrm{bp}$ of $16 \mathrm{~S}$ rDNA gene was generated from forward and reverse sequence data using aligner software. The $16 \mathrm{~S}$ rDNA gene sequence was used to carry out BLAST with the nrdatabase of NCBI genbank database. Based on maximum identity score first ten sequences were selected and aligned using multiple alignment software program Clustal W. Distance matrix was generated using RDP database and the phylogenetic tree was constructed using MEGA 4. The above genomic analysis was carried out by Disha life Sciences, Ahmedabad, Gujarat, India.

\section{$\mathrm{G}+\mathrm{C}$ content}

$\mathrm{G}+\mathrm{C}$ content of isolates were determined at the identification service of Genei; India. DNA was purified on hydroxyapatite according to the procedure of Cashion [7]. $\mathrm{G}+\mathrm{C}$ content was determined according to Mesbah [8] by using HPLC. GC content was calculated from the ratio of deoxyguanosine $(\mathrm{dG})$ and thymidine $(\mathrm{dT})$.

\section{Cellular fatty acid analysis}

Fatty acid and polar lipid content was determined as described by Nicolaus [9]. The fatty acid analysis was got done from Genei, Bangalore, India.

\section{Chromium reduction}

Chromium stock $\mathrm{K}_{2} \mathrm{Cr}_{2} \mathrm{O}_{7}(100 \mathrm{mM})$ was prepared of which $0.4 \mathrm{ml}$ was added to the serum bottles so as the final concentration of hexavalent chromium in Yeast Starch Soluable Broth medium - (g/l) Soluble starch 15; Yeast extract $0.4 ; \mathrm{K}_{2} \mathrm{HPO}_{4} 0.23 ; \mathrm{KH}_{2} \mathrm{PO}_{4} 0.2 ; \mathrm{MgSO}_{4} .7 \mathrm{H}_{2} \mathrm{O} 0.05$; Citric acid $0.052,1000 \mathrm{ml}$ distilled water; $\mathrm{pH} 5.5$ is $2 \mathrm{mM}$. The culture medium was inoculated with $1 \mathrm{ml}$ of the isolated culture. The bottle was sealed with rubber cap and aluminium foil seal to avoid medium evaporation and to maintain partial anaerobic conditions. A bottle was refrigerated ( $0 \mathrm{hr}$ for initial chromium). The rest of the bottles were incubated at $60^{\circ} \mathrm{C}$ for estimation of residual $\mathrm{Cr}(\mathrm{VI})$. A pair of bottles was removed after every $2 \mathrm{hrs}$ and was refrigerated. At the end of $24 \mathrm{hrs}$, all the refrigerated bottles were removed and the broth was subjected to centrifugation at 10,000 rpm for 10 mins. The supernatant was analysed for residual $\mathrm{Cr}(\mathrm{VI})$ content using diphenyl carbazide assay [10].

\section{Diphenyl carbazide assay for estimation of $\mathrm{Cr}$ (VI)}

Hexavalent chromium reacts with Diphenyl carbazide under acidic conditions to give a pink colour compound which is estimated spectrophotometrically.

\section{Results and Discussion}

\section{Enrichment and isolation}

Hot water was collected from Unhavre (Dhapoli) geothermal region. Both dilution plate and enrichment culture method were used. Enrichments were often conducted at high incubation temperatures $\left(70^{\circ} \mathrm{C}\right)$ regardless of the temperature of the collection site and the existence of temperature-adapted strains [11]. Isolates were obtained by directly streaking mat material onto solidified media or by directly adding undiluted inoculum to enrichment flasks. Both of these methods preclude attempts to measure the relative abundance of the microorganisms cultivated. The isolates were selected according to differences in their colony morphology. One of the isolated strains numbered $\mathrm{T} 4$ showing dense growth at $60^{\circ} \mathrm{C}$ was selected for further analysis.

\section{Phenotypic and physiological characteristics}

Yellow colored small colonies were obtained on Thermus agar medium on three days of incubation at $60^{\circ} \mathrm{C}$. The colonies were confirmed as Gram positive, short rods. This bacterial isolate T4 was identified by the biochemical tests and 16s RNA ribotyping as Anoxybacillus rupiensis.

Cells of isolate Anoxybacillus rupiensis appeared as motile, large rods, approximately 3.3-7.0 $\mu \mathrm{m}$ long and $0.7-1.5 \mu \mathrm{m}$ wide. Most cells occur in exponential growth phase singly or in chains. The cell 
Citation: Gursahani YH, Gupta SG (2015) Hexavalent Chromium Reduction by Anoxybacillus rupiensis isolated From Hot Water Spring of Dhapoli, Maharashtra, India. J Pet Environ Biotechnol 6: 232. doi:10.4172/2157-7463.1000232

wall structure is Gram positive. Terminal ellipsoidal or cylindrical endospores were observed. Yellowish colonies of about $5 \mathrm{~mm}$ in diameter with irregular margin are formed on peptone-yeast extract plates. Obligate thermophiles growing between 50 and $67^{\circ} \mathrm{C}$ (optimum $60^{\circ} \mathrm{C}$ ) and in a $\mathrm{pH}$ range from 5.5 to 8.5 (optimum 6.0-6.5). The isolate was able to utilize a broad spectrum of sugars, polysaccharides and polyols in the presence of proteinaceous substrates or inorganic nitrogen. Growth of Anoxybacillus rupiensis was observed in media containing ribose, xylose, fructose, glucose and maltose and no growth was observed on galactose, L-rhamnose, raffinose, sucrose and lactose containing media. Acid but no gas was produced by sugars. Anoxybacillus rupiensis degraded starch and xylan and not inulin and pectin. Growth is supported by manitol but not by ribitol, galactitol and sorbitol. Casein was hydrolysed, but not gelatin. Citrate was not utilized. Phenylalanine was not deaminated, tyrosine was not degraded, nitrate was not reduced, indole was not produced, the Voges-Proskauer reaction was negative, catalase reaction is positive and methyl red test was negative.

\section{Phylogenetic affiliation}

The 16S rRNA gene sequences were assembled after a minimum of $2 \mathrm{X}$ sequencing coverage for each base position. The obtained sequences were edited and $\mathrm{G}=\mathrm{C}$ mol\% and sequence similarity was determined. The sequences were aligned with the sequence of E. coli (GenBank accession no. J01695 [12] and nucleotides were determined in diagnostic positions [13]. Phylogenetic tree obtained according with the bootstrap test suggested by Felsenstein. The size of the 16s rRNA gene used for alignment was 1507 nucleotides. Since the sequence length used was complete. Tree obtained can be accepted for determining the phylogeny of the isolated strain [14]. The phylogenic tree. Figure 1 showed that the position of isolate Anoxybacillus rupiensis among the species of genetic group 5 of endospore forming bacteria. The phylogenetic tree in Figure 1 shows that isolate Anoxybacillus rupiensis is positioned between Geobacillus species from one side and Anoxybacillus species from the other side. The closest sequence relatives found by BLAST search was NR_042379.1 Anoxybacillus rupiensis strain DSM 17127 and Geobacillus tepidamans strain GS5-97, NR 025819.1 (96.8\% similarity), i.e., more than the level (3\% distance) over which strains are generally attributed to separate taxa [15] Except for G. tepidamans, the similarity between $\mathrm{T} 4$ and other species in the genus Geobacillus was less than $91 \%$. According to Schaffer [16] the observed levels of 16 S rRNA gene sequence similarity in this genus are higher than $96.5 \%$, and Geobacillus tepidamans is phylogenetically close to Anoxybacillus species [17]. On the basis of phylogenetic similarity with Anoxybacillus species, our isolate T4 was related to genus Anoxybacillus.

\section{Fatty acid profile}

The $\mathrm{G}+\mathrm{C}$ content of the genomic DNA for the isolate Anoxybacillus rupiensis was $41.7 \mathrm{~mol} \%$. The value obtained is significantly lower than those for the genus Geobacillus (48.2-58 mol\%) [18] and similar to the closest Anoxybacillus relatives (A. amylolyticus 43.5 mol\%; A. voinovskiensis $43.9 \mathrm{~mol} \%$; A. contaminans $44.3 \mathrm{~mol} \%) . \mathrm{G}=\mathrm{C}$ content of DNA was $43.2 \mathrm{~mol} \%$ for G. tepidamans [19]. The fatty acid profile of the isolate Anoxybacillus rupiensis was largely composed

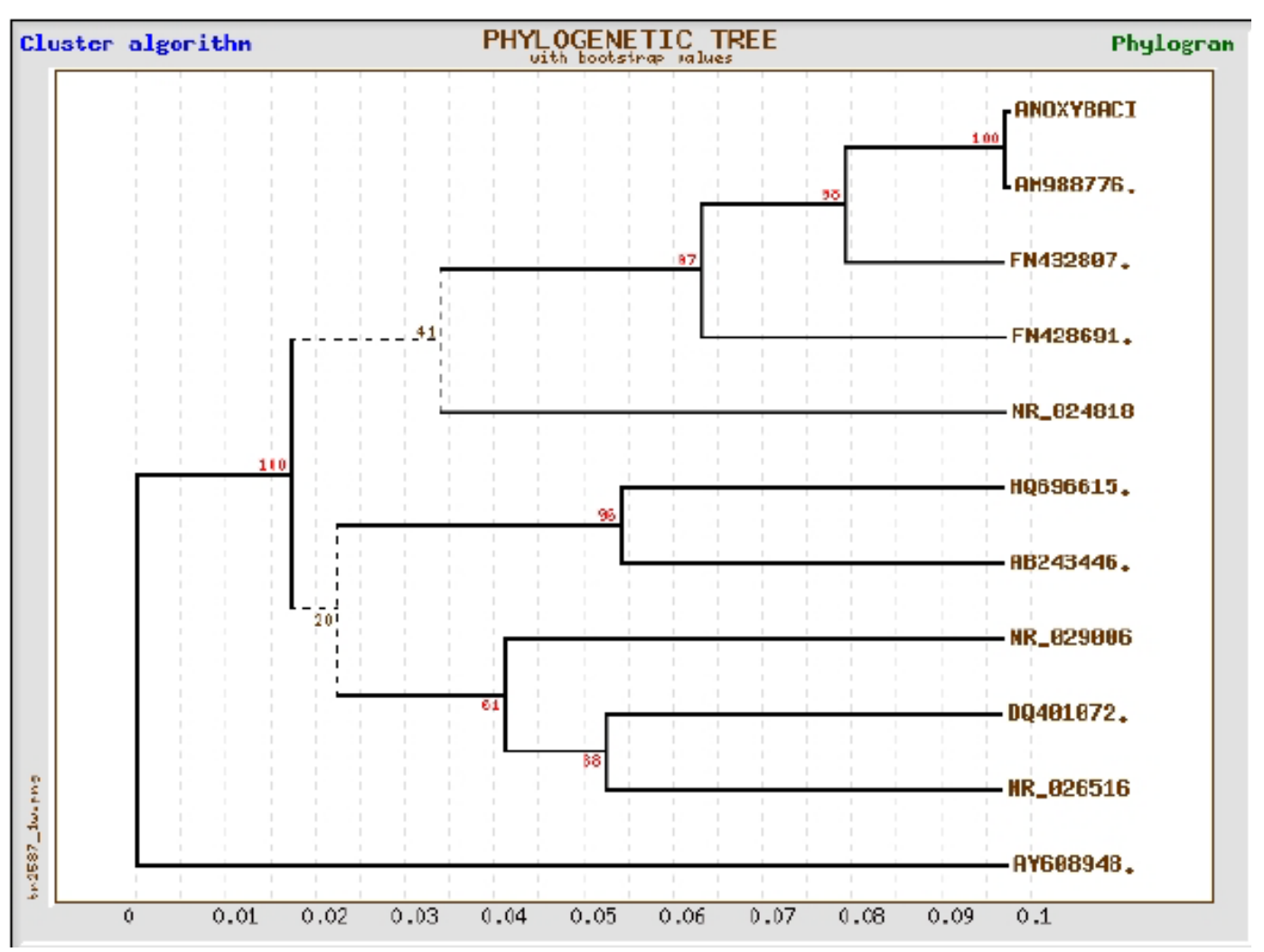

Figure 1: Phylogenetic tree of isolate T4. 16S rDNA sequence based phylogenetic neighbor joining tree showing the phylogenetic relationship of isolate T4 relative to the type strains of species in the genera Geobacillus, Anoxybacillus and sequences for NR_042379.1 Anoxybacillus rupiensis strain :DSM 17127 ; NR_042225.1 Anoxybacillus amylolyticus strain : MR3C; NR_024818.1 Anoxybacillus voinovskiensis strain TH13; NR_029006.1 Anoxybacillus contaminans strain R-16222; NR 025819.1 Geobacillus tepidamans strain GS5-97; NR 041915.1 Anoxybacillus kamchatkensis strain JW/VK-KG4; NR 026516.1 Anoxybacillus flavithermus strain DSM 2641; NR_036770.1 Saccharococcus thermophilus strain 657 16S. Bootstrap values (\%) from 1,000 replicates are as shown. 
Citation: Gursahani YH, Gupta SG (2015) Hexavalent Chromium Reduction by Anoxybacillus rupiensis isolated From Hot Water Spring of Dhapoli, Maharashtra, India. J Pet Environ Biotechnol 6: 232. doi:10.4172/2157-7463.1000232

Page 4 of 5

of branched saturated members and like other thermophilic bacilli contain anteiso-fatty acids as minor components (Table 1). Members of the genus Anoxybacillus contain iso-branched saturated fatty acids (iso-C15:0 and iso-C17:0) as major fatty acids. The major cellular fatty acids for R270T [20] were iso-C15:0 and iso-C17:0 (86.36\% in total). Those values for other genus representatives were: $78.16 \%$ for $A$. kestanbolensis KT4 [21] 72.8\% for A. amylolyticus [22] thermoleovorans 21.0\%; G. thermoglucosidasius 10.4\%; G. thermodenitrificans $9.5 \%$; G. stearothermophilus 6.2\%).

Although the isolate T4 (Anoxybacillus rupiensis) was consistently significantly similar to strain R270T (in their physiological properties, $16 \mathrm{~S} \mathrm{rDNA}, \mathrm{G}=\mathrm{C}$ value, low amount of iso-C16:0), it definitely differed from any other species in the genus Geobacillus in 16S rRNA gene similarity, $\mathrm{G}=\mathrm{C}$ value, iso-C16:0 content. The iso- $\mathrm{C} 16: 0$ (2.38\%) value for T4 (Anoxybacillus rupiensis) was similar to that for other Anoxybacillus R270T species and G. tepidamans and differed from other Geobacillus species (G. thermocatenulatus $31.8 \%$, G. thermoleovarans) published by Nazina et al. [23]. The similar physiological characteristics, $G=C$ content of DNA, fatty acid profile and phylogenetic similarity (95.3-94.9\%) to the closest relatives, A. rupiensis. $68.59 \%$, A. contaminans, and $65.7 \%$ A. voinovskiensis [24] with representatives of the genus Anoxybacillus allow us to place the isolate T4, in the genus Anoxybacillus, as the type strain for the novel isolate from Unhavre hot water spring (Dhapoli), Maharashtra, India.

\section{$\mathrm{Cr}$ (VI) reduction}

The percentage of chromate reduction by Anoxybacillus rupiensis is computed in Table 2. Anoxybacillus rupiensis showed $75 \%$ of $\mathrm{Cr}$ (VI) reduction after 24 hours of incubation at $60^{\circ} \mathrm{C}$. The enzymatic reduction of $\mathrm{Cr}$ (VI) by the above potential chromate reducer can be an alternative remedial method as compared to mesophilic species of Pesudomonas [25]. Smibert had showed that Deinococcus radiodurans

\begin{tabular}{|c|c|c|c|}
\hline Fatty Acids & T4 & R270T & C \\
\hline 10.0 & - & 0.30 & - \\
\hline $14: 0$ ISO & 1.3 & 1.64 & 2.13 \\
\hline $14: 0$ & 0.3 & 0.31 & 0.1 \\
\hline $15: 0$ ISO & 52.61 & 52.81 & 7.0 \\
\hline $15: 0$ ANTEISO & 1.56 & 2.01 & 0.12 \\
\hline $15: 0$ & 0.42 & - & 6.3 \\
\hline $16: 0$ isO & 2.38 & 3.94 & 2.13 \\
\hline $16: 0$ & 5.44 & 5.44 & 0.7 \\
\hline $17: 0$ Iso & 32.5 & 33.55 & 31.6 \\
\hline $17: 0$ anti-iso & 3.7 & 2.01 & 1.3 \\
\hline $17: 0$ & & - & 0.7 \\
\hline $18: 1$ isoH & & - & - \\
\hline $18: 1$ iso & 0.6 & - & - \\
\hline $18: 0$ & & - & 41.2 \\
\hline $18: 1$ & & 0.30 & 0.1 \\
\hline $19: 0$ iso & - & 52.81 & 7.0 \\
\hline UnsaturatedC:16 & 0.3 & 1.64 & \\
\hline Other & 0.1 & 0.31 & \\
\hline & & & \\
\hline
\end{tabular}

Table 1: Cellular fatty acid composition (\% w/w)

\begin{tabular}{|c|c|c|c|c|}
\hline \multirow{2}{*}{ Thermophilic bacteria } & \multicolumn{4}{|c|}{ Percent reduction of $\mathbf{C r}(\mathbf{V I})$ after } \\
\cline { 2 - 5 } & $\mathbf{5 ~ H r s}$ & $\mathbf{1 0} \mathbf{H r s}$ & $\mathbf{1 5} \mathbf{H r s}$ & $\mathbf{2 4} \mathbf{H r s}$ \\
\hline A. rupiensis & 68 & 68 & 73 & 75 \\
\hline
\end{tabular}

Table 2: Reduction of $\mathrm{Cr}(\mathrm{VI})$ by Anoxybacillus rupiensis was able to reduce $72 \%$ of the initial Cr (VI), after 14 days under anaerobic conditions.

\section{Conclusion}

Our results have confirmed that Anoxybacillus rupiensis is amongst the most promising thermophiles that could be exploited for the treatment of chromium bearing effluents. There is a scope of extending this experiment by using small molecular weight carbohydrates and organic acids, instead of starch that has been used in this experiment.

Hence, preliminary experiments on $\mathrm{Cr}$ (VI) reduction by selected thermophilic bacteria will attract researchers to carry out experiments on different aspects of thermophilic $\mathrm{Cr}$ (VI) reduction.

\section{References}

1. Pikuta E, Lysenko A, Chuvilskaya N, Mendrock U, Hippe H (2000) Anoxybacillus pushchinensis gen. nov $\mathrm{sp}$ nov a novel anaerobic alkaliphilic moderately thermophilic bacterium from manure and description of Anoxybacillus flavitherms comb nov. Intl J Syst Evol Microbiol 50: 2109-2117.

2. Pikuta E, Cleland D, Tang J (2003) Aerobic growth of Anoxybacillus pushchinoensis K1T emended descriptions of A pushchinoensis and the genus Anoxybacillus Intl J Syst Evol Microbiol 53: 1561-1562.

3. Yumoto I, Hirota K, Kawahara T, Nodasaka Y, Okuyama H (2004) Anoxybacillus voinovskiensis sp nov a moderately thermophilic bacterium from a hot spring in Kamchatka IntL J Syst Evol Microbiol 54: 1239-1242.

4. Gursahani YH, Gupta SG (2011) Decolourization of textile effluent by a thermophilic bacteria Anoxybacillus rupiensis. J Pet Environ Biotechnol 2: 1-4.

5. Goh KM, Kahar UM, Chai YY, Chong CS, Chai KP, et al. (2013) Recent discoveries and applications of Anoxybacillus. Appl Microbiol Biotechnol 97: 1475-1488.

6. Holt JG, Krieg NR (1994) Enrichment and Isolation and Methods for General and Molecular Bacteriology. (ASM Publications) pp: 197-200.

7. Cashion P, Holder Franklin M, McCully J, Franklin M (1977) A rapid method for the base ratio determination of bacterial DNA. Anal Biochem 81: 461-466.

8. Mesbah M, Premachandran U, Whitman WB (1989) Precise measurement of the $\mathrm{G}+\mathrm{C}$ content of deoxyribonucleic acid by high-performance liquid chromatography . Intl J Syst Bacteriol 39: 159-167.

9. Nicolaus B, Lama L, Esposito M, Manca G, Gambacorta PA (1978) Bacillus thermoantarcticus sp Nov from Mount Melbourne Antarctica a novel thermophilic species Polar Biol 16: 101-104.

10. Urone PF (1995) Stability of colorimetric reagent for chromium, s-diphenylcarbazide in various solvents Anal Chem 27: 1354-1355.

11. Castenholz RW (1981) Isolation and cultivation of thermophilic cyanobacteria In: Starr MP, Stolp H, Trüper HG, Balows A, Schlegel HG (eds.) The prokaryotes - A handbook on habitats isolation and identification of bacteria. Springer Verlag, NewYork, USA pp: 236-246.

12. Brosius J, Palmer P, Kennedy J, Noller HF (1978) Complete nucleotide sequence of a $16 \mathrm{~S}$ ribosomal RNA gene from Escherichia coli. Proc Natl Acad Sci USA 75: 4801-4805.

13. Ash C, Farrow J, Wallbanks E, Collins M (1991) Phylogenetic heterogeneity of the genus Bacillus revealed by comparative analysis of small subunit ribosomal RNA sequences. Letters in Appl Microbiol 13: 202-206.

14. Stackebrandt E, Goebel BM (1994) Taxonomic note: a place for DNA-DNA reassociation and $16 \mathrm{~S}$ rDNA sequence analysis in the present species definition in bacteriology. Intl J Syst Evol Microbiol 44: 846-849.

15. Nazina TN, Taurova A, Poltaraus EV, Novikova AA, Grigoryan AE (2001) Taxonomic study of aerobic thermophilic bacilli descriptions of Geobacillus subterraneus gen nov sp nov and Geobacillus uzenensis sp nov from petroleum reservoirs and transfer of Bacillus stearothermophilus Bacillus thermocatenulatus Bacillus thermoleoeorans, Bacillus kaustophilus Bacillus thermoglucosiiasius and Bacillus thermoienitrificans to Geobacillus as the new combinations $\mathrm{G}$ stearothermophilus $\mathrm{G}$ thermocatenulatus $\mathrm{G}$ thermoleoeorans $\mathrm{G}$ kaustophilus $G$ thermoglucosiiasius and $G$ thermoienitrificans. Intl J Systematic and Evolutionary Microbiol 51: 433-446. 
Citation: Gursahani YH, Gupta SG (2015) Hexavalent Chromium Reduction by Anoxybacillus rupiensis isolated From Hot Water Spring of Dhapoli, Maharashtra, India. J Pet Environ Biotechnol 6: 232. doi:10.4172/2157-7463.1000232

Page 5 of 5

16. Schaffer C, Franck WL, Scheberl A, Kosma P, McDermott TR (2004) Classification of isolates from locations in Austria and Yellowstone National Park as Geobacillus tepidamans sp nov. Intl J Syst Evol Microbiol 54: 2361-2368.

17. Atanassova M, Derekova A, Mandeva R, Sjøholm C, Kambourova M (2008) Anoxybacillus bogrovensis sp nov a novel thermophilic bacterium isolated from a hot spring in Dolni Bogrov Bulgaria. Intl J Syst Evol Microbiol 58: 2359-2362.

18. Dülger S, Demirbağ Z, Beldüz AO (2004) Anoxybacillus ayderensis sp nov and Anoxybacillus kestanbolensis sp nov Intl J Syst Evol Microbiol 54: 1499-1503.

19. Fredrickson J, Kostandarithes H, Daly M (2000) Reduction of $\mathrm{Fe}(\mathrm{III}) \mathrm{Cr}(\mathrm{VI}) \mathrm{U}$ (VI) and Tc (VII) by Deinococcus radiodurans R1. Appl Environ Microbiol 66: 2006-2011.

20. De Clerck E, Rodriguez Diaz M, Vanhoutte T, Heyrman J, Logan NA, et al. (2004) Anoxybacillus contaminans sp nov and Bacillus gelatini sp nov isolated from contaminated gelatin batches. Intl J Syst Evol Microbiol 54: 941-946.

21. Felsenstein $J(1985)$ Confidence limits on phylogenies An approach using the bootstrap. Evolution 39: 783-791.

22. Mora B, Fortina MG, Nicastro G, Parini C, Manachini P (1998) Genotypic characterization of thermophilic bacilli a study on new soil isolates and several reference strains. Microbiol 149: $711-722$.

23. Opperman DJ , Van Heerden E (2006) Aerobic $\mathrm{Cr}(\mathrm{VI})$ reduction by Thermus scotoductus strain SA-01. J Appl Microbiol 103: 1907-1913.

24. Paul SC, Jain P, Mitra J, Dutta S, Bhattacharya $P$ (2012) Induction of $\mathrm{Cr}(\mathrm{VI})$ reduction activity in an Anoxybacillus strain under heat stress: a biochemical and proteomic study. FEMS Microbiol Lett 331: 70-80.

25. Smibert R, Krieg N (1981) General characteristics. 